\title{
Chinese categorization of interpersonal relationships and the cultural logic of Chinese social interaction: An indigenous perspective
}

\author{
ZHENGDAO YE
}

\section{Abstract}

This paper explores the conceptual basis of Chinese social organization, and examines how the fundamental Chinese categories of interpersonal relationships affect Chinese ways of speaking and social interaction. Firstly, the paper will analyze the full meanings and interrelationship of two of the most distinctive (complementary) dyads of Chinese social categories, namely, shēngrén (lit. "uncooked person", "stranger") vs. shúrén (lit. "cooked person", "an old acquaintance"), and zijürén (lit. "oneself person", "insider") vs. wàirén (lit. "outer/outsider person", "outsider"). It will then put forward two master scripts-general principles underlying norms of social interaction - in Chinese culture that are governed by the demarcations of these fundamental categories: nèiwàiyŏubié ("difference between the insider and outsider") and yóushūzhìīn ("from far to close"), and illustrate aspects of Chinese language use that are guided by these principles. They include dă zhāohu ("greetings"), the use of tóng X ("fellow $X$ ") and lăo X ("old X"), and a brief discussion of the value of not being polite in Chinese culture. On the one hand, this paper demonstrates the need for treating interpersonal relationships as a theoretical variable in the study of human interaction and shows the importance of an indigenous perspective; on the other, it relates theoretical discussion of human interaction to practical needs of understanding Chinese interactional style for the purpose of language teaching and political and commercial negotiations. Both goals can be attained by the use of the Natural Semantic Metalanguage and "cultural scripts" theory.

Keywords: cultural scripts, interpersonal relationships, social categories, insider-outsider, Chinese communicative style 


\section{Why "interpersonal relationships"? Background, methodology and objectives $^{1}$}

There are two major factors that have inspired this study to focus on interpersonal relationships. Firstly, social interaction occurs between people. How people interact with each other, verbally and nonverbally, depends, to a large degree, on their perceived social relationships. Secondly, interpersonal relationships play a fundamental, even decisive, role in Chinese social interaction. Understanding how interpersonal relationships are categorized in the Chinese culture is key to understanding the social behavior of the Chinese people, as will be amply shown in the rest of the paper.

Intuitively and empirically important as they are, interpersonal relationships have not received due attention from pragmatic theorists and have never been treated as a legitimate theoretical variable in the existing literature on pragmatics, not even in the literature on Chinese pragmatics and social interaction. This may not come as a surprise, as most of the effort in researching Chinese ways of speaking seems to have been directed at testing "universal models", which have been developed predominantly on the basis of Anglo cultural experience. The irony is that Anglo culture may be one of the few cultures where the role of interpersonal relationships happens to be decentered, owing to the general cultural ethos that drives at an autonomous and independent (rather than interdependent) self (Marcus and Kitayama 1991).

To test empirically the validity of proposed universal models is necessary and important. But when most of the tested "universal" models are generated from one cultural perspective and other cultures become mere testing grounds, there is a danger of creating cultural blind spots. The present study pays attention to a "blind spot" that has been created by a single Anglo perspective, which, when viewed in the Chinese culture "proper", holds the key to understanding Chinese interactional style.

Thus, this study attempts to depart from those studies on Chinese pragmatics intent on testing the existing "universal" models of social interactions. It will attend to a much neglected indigenous perspective, turning to Chinese culture itself and examining what is basic, important, and fundamental to the Chinese people themselves in their social reality.

When it comes to adopting an indigenous or culture-internal perspective, especially for an audience from other lingua-cultural backgrounds, methodological issues concerning the descriptive tool become particularly important. Two major methodological concerns stand out: the first, how the full meanings of indigenous concepts and categories, and norms of social interaction, can be explained adequately and precisely to cultural out- 
siders, and the second, how the descriptive tool can be as culture sensitive as possible, so as to reduce the cultural bias built within the descriptive tool itself. In other words, an ideal descriptive tool is one that comprises maximally culture-independent metalanguage and that can serve as an adequate framework to interpret and represent meanings. In this regard, the Natural Semantic Metalanguage (NSM) and its branch of "cultural scripts" theory (e.g., Wierzbicka 2003b; the Introduction of this volume) provides a satisfying solution.

It is, therefore, the objective of this paper to use the NSM theory as a descriptive method (in particular the English version of the metalanguage) to explore the conceptual basis of Chinese social organization, and to examine how the fundamental categorization of interpersonal relationships guide Chinese ways of speaking and social interaction. In doing so, the paper also endeavors to relate theoretical discussion to the practical needs of understanding Chinese interactional behavior in intercultural encounters, such as political and commercial negotiations.

\section{Some fundamental categories in the Chinese conceptualization of interpersonal relationships and their explications}

In a rare and highly revealing ethnographic study of Chinese face-to-face interaction using a situation-based approach, the author Pan Yuling comes to the conclusion that "Chinese tend to employ different politeness strategies depending first on their knowledge of the addressee and then on the situation" (Pan 2000: 20). In studies on the psychology of the Chinese people (e.g., Gao et al. 1996), "insider effects" are cited as playing an important role in Chinese social interaction. But what does the phrase "insider effects" mean? What does "the knowledge of the addressee" entail? This section seeks to answer these two questions by examining in detail the meanings of two of the most distinctive dyads of (complementary) categories of interpersonal relationships: shēngrén ("stranger") vs. shúrén ("acquaintance"), and zijjurén ("one of us") vs. wàirén ("outsider"). ${ }^{2}$

\section{1. shēngrén 生人 (“stranger") vs. shúrén 熟人 ("acquaintance”)}

Shēngrén [uncooked/unripe/unfamiliar-person] ("stranger") and shúrén [cooked/ripe/very familiar-person] ("an old acquaintance") is a highly salient dyad of concepts in the Chinese language, reflected in commonly used idioms such as the following: 
(1) $y \bar{\imath} \quad$ huí shēng,
one CL:round uncooked/unfamiliar two CL:round
shí
cooked/familiar
'Strangers at the first meeting but friends at the second.'

The meanings of this dyad of concepts can be explicated as follows (a Chinese version of $[\mathrm{A}]$ is in the Appendix):

[A] Explication for Chinese shúrén

(a) people can think about some people like this:

(b) "I have known for some time who this person is

(c) this person has known for some time who I am

(d) some time before, I could not think like this

(e) after this, when I saw this person, I said some things to this person

(f) at the same time this person said some things to me

(g) it happened like this for some time

(h) because of this, I can now say things to this person like people say things to someone when they know who this someone is"

(i) people can't think about all people in this way

(j) they have to think about some people in another way

[B] Explication for Chinese shēngrén

(a) people have to think about some people like this:

(b) "I don't know who this person is

(c) I can't say things to this person like people say things to someone when they know who this someone is"

As mentioned, shēngrén ("stranger") and shúrén ("acquaintance") are a dyad of complementary concepts. This means that these two concepts evoke each other, sharing a common, shifting boundary. Together they form the whole of a non-kinship group: outside the circle of family members and relatives, one is either a shúrén or a shēngrén to the central figure, depending on whether the central figure has had previous, mutual face-to-face communication with the referent person, as a result of which these two people have "got to know" each other. For a Chinese, someone who looks miànshú [face-familiar] but to whom one has never said anything, is still a shēngrén ("stranger") (cf. (d)-(g)).

From shēng [uncooked/unripe/unfamiliar] to shú [cooked/ripe/ familiar], it is apparent that duration of time is seen by the Chinese people as the basis of conceptualizing human relations. Over the course of time, 
people become familiar with each other. This "time factor" is easily discernible in the following exchange between the interviewer and the interviewee (see also §4.3):

(2) Interviewer: So how did you become the boss here?

Yang: After I resigned, I went to work in another restaurant, which was closer. He just got divorced then and lived alone. He often came to eat noodles. With the passage of time, we got familiar [shú] ... It was just like that. $\left(\right.$ Chen 2003: 230) ${ }^{3}$

A shúrén might be rendered in colloquial English as "a person one knows", and a shēngrén as "a person one does not know". However, these are English-specific expressions, thus they are avoided in the explication. Firstly, the phrase "know someone" is problematic in English (cf. Wierzbicka 2002). Furthermore, there is not one-to-one matching with the Chinese expressions. In the Chinese language there are three words_zhìdào, rènshi, and liáojiě - that can all be translated as know in English. Zhìdào is used for "factual knowledge" (e.g. "I know that_"). Rènshi has more to do with recognition (of identity) based on previous experience or contact. Thus to say Wŏ rènshi zhège rén/difäng ("I know this person/place") implies that I have said something to this person when I was with this person or have been to this place before (therefore when I see this person/this place again, I can say who this person is or where this place is). Liáojiě is to "know" in the sense of "knowing something/someone/some place well", closer to the meaning of understand ("I know what it/this person/this place is like; I can say many things about it/this person/this place; I can say why this something/this person/this place is like this"). Thus, expressions like I know this person, though simple, are avoided in the explications, because they are English-specific, and can be further explained via simpler concepts on the basis of how personal knowledge is constructed and understood in a culture. The KNOw used in the explications is in the sense of "factual knowledge" only, whose universality is well-established in the NSM framework (see Goddard and Wierzbicka eds, 2002).

\section{2. zijurrén 自己人 (“insider" / "one of us") vs. wàirén 外人 ("outsider”)}

Another important dyad of complementary categories which has a decisive effect on Chinese social interaction is zijürén [self/oneself-person] ("insider", "persons within the same circle; persons closely related with each other", "one of us") and wàirén [outside/outer-person] ("outsider"). Their meanings can be explicated as follows: 
[C] Explication for Chinese zij̄irén

(a) people can think about some people like this:

(b) "these people live in one place

(c) I am one of these people

(d) I do many things with these people

(e) these people can know many things about me

(f) I can say many things to these people

(g) I can't say all these things to other people

(h) when I think about these people, I feel something good

(i) when these people want me to do good things for them, I have to do something good for these people"

(j) other people are not like this, I have to think about them in another way

[D] Explication for Chinese wàirén

(a) people think about some people like this:

(b) "I can't think about these people like I think about zijirrén

(c) I can't say things to these people like I say things to zijirrén

(d) I don't have to do good things for these people like I have to do good things for zijürén

(e) I don't want these people to know many things about me"

A ziǰrrén ("insider") is someone who lives in one place and is a part of a group (b)-(d), whom I can trust (e)-(g), have good feelings about (h), and who has certain obligations (i).

The demarcation between zijürén and wàirén is fundamentally a psychological one, unlike that of shēngrén and shúrén, which is experientially based. The zìjurén-wàirén distinction is demarcated by whether "these people" are like a group living together in one place. Arguably, the prototype of people living in one place as a group in traditional China are family members-jiärén [extended family-person], who are also related kinship members at the same time (bound by blood relation or marriage). It is not surprising that the default zijurién is a jiārén ("extended familyperson"), and that a variant of zijirén is zijiärén (in which jiā means extended family). Thus the mere mention of wàirén means someone who is outside one's family circle. All these considerations suggest that no matter how large the zijurén circle is, it is always modelled after the implicit family.

In a sense, shēngrén and shúrén can always exist independently: a shēngrén can become a shúrén to the speaker, who a shēngrén is is not determined by who a shúrén is; whereas a wàirén ("outsider") is always dependent on who a zijürén ("insider") is. A wàirén cannot exist without some implicit reference to a ziǰirén. Therefore, in the wàirén-zijjurén continuum, 
they are relative and relational concepts: wàirén not only evokes zijirrén, but is heavily dependent on it, and is marked. This dependence is reflected in the above explications, in that the concept of zijurién is present and embedded in the explication of wàirén. And the explication of wàirén ("outsider") clearly shows that the central figure adopts a different attitude (such as mistrust, indifference) towards wàirén.

Arguably, psychological affinity and category based on related people (kinship members) living in one place is often stable, deeply-rooted, and resistant to change. ${ }^{4}$ With the passage of time and more contact, a shēngrén ("stranger") automatically becomes a shúrén ("acquaintance"), but does not necessarily move along the wàirén-zijizrén continuum, where the boundary is more fixed. A wàirén may forever remain an outsider.

Fei Xiaotong, the first Chinese anthropologist, describes one of the features of Chinese social networking as chäxù géjú (often translated by social scientists as "differential order"), where each person is at the centre of his or her concentric social network (Fei 1937). The above analysis and explication show that zijjurén is "my" immediate, inner circle, that shúrén fills the next, intermediate ring of the circle, and that shêngrén occupies the outer or peripheral circle, which is farthest from "me" (see Figure 1.).

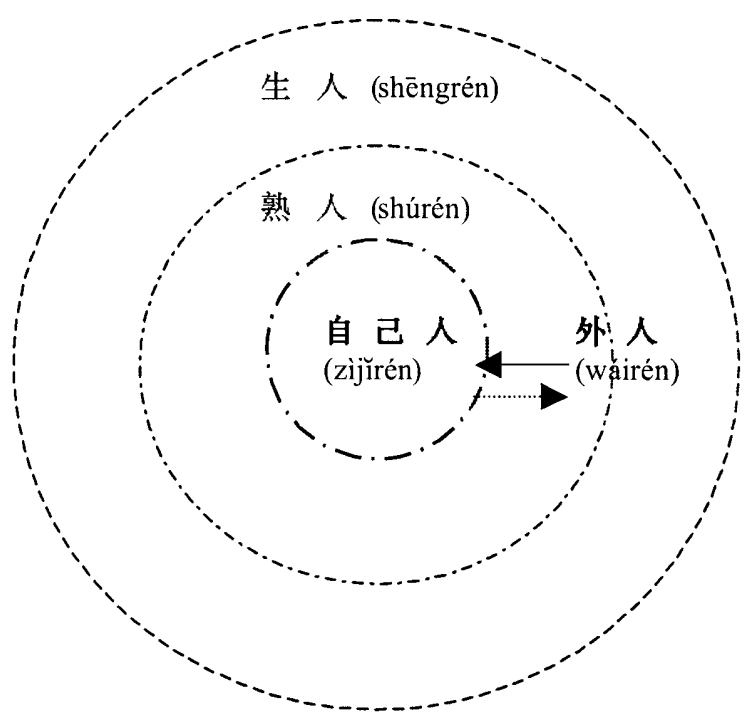

Figure 1. 
2.3. Why are "insider", "outsider", "in-group", "out-group” not good descriptions?

It is easy to gloss the above-mentioned Chinese social categories as "stranger", "acquaintance", "insider" and "outsider", or to use the more technical terms "in-group" and "out-group". However, these terms do not reflect the interrelationships of these categories, or reveal anything of their deep conceptual structures. Nor do they reflect their keyword status in Chinese culture.

\section{Two "master scripts" of Chinese social interaction}

The distinctive categories discussed above and their conceptual interrelationships have a decisive effect on Chinese interactional styles. This section will focus on two of the "master scripts", two general principles underlying Chinese social interaction that operate on these categories.

\section{1. nèiwàiyŏubié 内外有别 ("insider and outsider have difference")}

The first principle is captured in the Chinese set phrase nèiwàiyounbié [insider/inner-outside/outer-have-difference]:

[E] Cultural script

[people think like this:]

I can't say things to all people in the same way

(because I can't think about all people in the same way)

I can say things to shúrén in some ways

I can't say things to shêngrén in the same way

I have to say things to shēngrén in some other ways

I can say things to zijurén in some ways

I can't say things to wàirén in the same way

I have to say things to wàirén in other ways

This script shows that social categories are embedded in the shared knowledge of the Chinese people as to the ways in which they should interact with other people. The differentiated way of interacting with shēngrén and shurrén is reflected, for example, in the following article title: shúrén xūhánwénnuăn, shēngrén àidābùlı̆ ("acquaintances warmly welcomed, strangers indifferent", [http://www.cityclassic.com, last accessed on April $\left.\left.9^{\text {th }}, 2004\right]\right)$. It is also reflected in commonly used idioms such as jiāchŏu bùkě wàiyáng ("family scandals should not be known to the outsiders"). A final example, which is taken from a personal account of a 
non-local worker in Shanghai, reflects the principle embodied in explication [D] from another angle:

(3) It is after all their territory here. We, the non-local [wàidi, lit. "outsider/other-place"] workers, will not be treated as "one of us" [zijirrén] by them. Although they are very polite [kèkèqiqi, see §5] on the surface, I can sense that they are cold and indifferent. (Chen 2003: 230$)^{5}$

\section{2. yóushūzhìqīn 由疏至亲 (“from far to close”)}

Because of the axiomatically different attitude towards different categories of people, it can be expected that, in social interaction, a great deal of effort is invested on the part of the interactants to work towards or to display a closer relationship: from "strangers" to "old acquaintances", and ultimately to "us", the inner circle (like members of family). Thus the driving force of Chinese social interaction is to move along the wàirén-zijurrén continuum, so as to shorten the horizontal distance between interactants, so that the relationship between the central figure (the speaker) and the referent person can move from being $s h \bar{u}$ ("far/distant/thin") to qin ("close/intimate") Note that qin ("close") and $\operatorname{sh} \bar{u}$ ("far") is a set of opposites used exclusively to describe relational (not physical) distance and to modify guänxi ("relationship"). ${ }^{6}$ The existence of such specialized words shows the importance of the role of relationships in the Chinese social realm. The second master script on Chinese social interaction can be formulated as follows:

[F] Cultural script

[people think like this:]

it is good if some people think about me like this: this person is a zijirén

because of this, it will be good if I say things to these people in the way like I say something to a zijirrén

In order for the relationship between interactants to draw closer towards the central figure (as indicated by the solid arrow in Figure 1), one essentially extends the model of social interaction adopted within the Chinese family (where kinship members live in one place) to non-family (nonkinship) members [like I say something to a zijurién]. This is done through linguistic strategies (the perforated arrow in Figure 1 shows this direction of linguistic extension). The next section will highlight and examine some of the "pragmatic acts" (Mey 2001) employed to achieve this goal. 


\section{How does Chinese conceptualisation of interpersonal relationships affect Chinese social interaction?}

The purpose of this section is to discuss lower-level, more specific scripts governing Chinese language use, which are guided by the master scripts discussed in the previous section. In particular, it will examine the following four aspects of language use in Chinese: dă zhāohu ("greeting"), the use of tóng $X$ ("fellow X") and lăo $X$ ("Old X"), and the "not-beingpolite" phenomena. Because the shúrén ("acquaintance") form the intermediate, transitional circle, it can be expected that this is where the dynamism of Chinese social interaction lies.

The discussion below is based on hard linguistic evidence, on observations from literature on negotiation, and on what Wierzbicka (2003a) calls "soft linguistic data", which in the case of this paper is my own experience as a Chinese immigrant in Australia (e.g., Ye 2004a). Immigrants are not only best placed to testify to cultural differences, but their experience constitutes a valuable empirical source for studying real-life intercultural encounters.

\section{1. dă zhāohu 打招呼 (“greeting”)}

The first "pragmatic act" that this paper investigates is $d \breve{a} z h \bar{a} o h u$ ("greeting"). Chinese babies from a very early age begin to be socialized to perform this act. The following excerpt translated from an article entitled Liùgeyuè de háizi hui shěnme? ("What can a six-month baby do?"), which appeared on Chinese Paediatrics Web, an authoritative website run by the Department of Paediatrics, Beijing University, provides a good example:

(4) Babies begin to have differentiated recognition of people after a period of general recognition. They start to show shyness or timidity. This shows improvement on the part of the baby. At this time, more opportunities for contact with other people should be encouraged, and parents should observe his or her reaction to shúrén and shēngrén. Parents should teach the baby to use smiles or vocalization to greet [dă zhāohu] shúrén ("acquaintance") and get more used to shēngrén ("stranger") [http://ek.med618.com.cn, last accessed April $\left.9^{\text {th }}, 2004\right]$

This example shows clearly how the cultural script shown in [E] operates in the socialization of very young children. The cultural pressure is to greet shúrén ("acquaintance"), verbally and/or non-verbally, obligatorily. I will adduce examples from the internationally well-known Chinese film Qiūjú Dăguānsi (The Story of Qiuju, hereafter SQ) to further illustrate 
this point. Throughout this film, dă zhāohu never takes place between strangers, not even in the situations where "greetings" are expected by Anglo cultural norms. A telling example is at the beginning of the film when the protagonist Qiuju takes her injured husband to see a physician at a country clinic. There was no exchange such as "hello" or "how are you" between doctor and patients when they come into each other's field of vision. The doctor simply asked "Zënmele?", which means "What happened (to you)?"

What do shúrén ("acquaintance"), or participants (in the sense of P in Hymes' (1962) SPEAKING model), say to each other in this "greeting" act? The following examples from SQ are highly representative:

(5) [Entering the inner room of the village head's house and seeing his mother eating noodles on the kang. A: Qiuju, B: village head's mother]

A: Chīmiàn? [eat-noodle] You are eating noodles (aren't you)?

B: Chīmiàn. Nǐchī géinī chéng. [eat-noodle. You-eat-give-you-dish out] Yes, I will give you some (giving the bowl to Qiuju).

A: Wŏ chīguòle. Nǐchī [I-eat-EXP] I have eaten. You eat.

(6) [A: Police Li, B: village head]

B: [seeing Police Li come in] Shàngláile? [up-come-PFv] You've come (haven't you)?

A: Eh, shàngláile. [yes, up-come-PFv] Mógŭ'a? [grind-crop-Q] Yes, I've come. You are grinding the grain, (aren't you)? [Old Wang, as to the matter of ...]

What is common to these examples is that participants in the act of "greeting" ask the obvious about what the other person is doing. ${ }^{7}$ The question is often met with an affirmative answer (but can be negative) or, sometimes, it does not anticipate an answer such as in (6). For example, seeing a fellow colleague returning to the office, one can greet her/ him with something like "You've come back, haven't you" and then go on to some other topic. Walking into another colleague's office and seeing that this colleague is busy writing, the speaker can say something like "You are busy writing, aren't you". One of the functions of "asking the obvious" is surely to acknowledge the presence of the other person (Firth 1972: 9-11). However, by observing and paying attention to what the other person is doing, and seeking further confirmation of information concerning the other party, the speaker reconfirms his or her relationship with the addressee. Each time such a communicative act is performed, the relationship between the interactants naturally becomes a step closer, and more and more shú ("familiar"). 
Having been immersed in the "how are you?" type of greeting in Australia, I was always struck by what Chinese people say to acquaintances in similar situations. Common exchanges could include (the Chinese equivalents of) (a) "Aunty X, you are going (grocery) shopping?" (b) "You are going out?" (c) "Teacher Zhou, you are going out with your daughter?" (d) "Master Li, you are coming back from work?" The answers could be (a) "I am going to the supermarket to buy some meat, my daughter is coming for dinner", (b) "The weather is nice, I am going out just to look around", (c) "I am taking my daughter to buy some clothes", and (d) "I am coming back from work". On campus in Australia I often had the urge to say something like "you are going to the library (aren't you)" upon seeing an acquaintance or "you are reading a book, (aren't you)" if inside the library. But I held back because I knew it was not the Anglo way of greeting.

The fact that Chinese people ask the obvious about what the other person is doing also makes Chinese "greetings" less formulaic, but more creative, depending on what the other person is doing at the time of speaking (and the answers could be elaborated). Duranti (1997) points out that greetings are not necessarily devoid of propositional content, as is often assumed in pragmatic studies. He considers it important to examine what people say in "greetings". The analysis in this section supports Duranti's position. ${ }^{8}$ The following is a script proposed for dă zhāohu (There is a non-verbal script which accompanies script [a], see Ye 2004b, in press):

[G] Cultural script for dă zhāohu ("greeting")

[people think like this:]

when I see a shúrén, if I have not seen this person for some time

I have to say something like this to this person:

"I see you now

because of this I know that you are doing something now

I want to know more about it"

if I say this, this person can think because of this that I feel something good towards this person

if I don't say this, this person can think that I feel something bad towards this person

I don't have to say something like this to a person if this person is not a shúrén

$D \breve{a} z h a \bar{o} h u$ has to take place in face-to-face interaction [when I see a shúrén]. One can put greeting in the email subject column, but one cannot do so with dă zhāohu. ${ }^{9}$

In Anglo culture, a person greets someone they know. But the interesting thing is that it is also considered friendly to greet a stranger, thus the 
encouragement of "How are you?" in service encounters. One can imagine how a Chinese used to the above script will react to the quasi-obligatory "How are you?" in supermarkets in Australia; and conversely, how a native English speaker used to greetings in services exchanges (including in hospitals) would feel without the "How are you?" or smiles in the comparable situations in China.

In a changing China, wēixiào fúwù ("smile service") is being increasingly advocated, especially in cosmopolitan cities. But people generally take it with a grain of salt. The impersonal, unsmiling huānying guānglín ("Welcome to come here") fulfils such a need in public service encounters. This, from another angle, affirms the shared knowledge of not greeting a shēngrén implied in the last line of the script.

\section{2. tóngX 同 $X$ (“fellow $X$ ")}

A shúrén ("acquaintance") is not automatically qualified as a zij̄irén ("insider/one of us"). As mentioned earlier, zijurrén is a psychological category, usually predetermined by some pre-set shared traits such as blood or place relations (that is, people who are from the same place). For a non-kinship member to be considered as a zijurrén, Chinese people have to appeal to some "sameness" shared by the interactants. This is why they often refer to each other as tóng $X$, which could roughly be translated into English as "fellow X". Not surprisingly, there is a proliferation of tóng [same]-related phrases to refer to such "sameness" in the Chinese language. Some most commonly used "referents" are as follows (all from DeFrancis 1997: 600-604): tóngxiang [same-town] ("fellow villager/townsman"), tóngxué [same-study] ("fellow student" or "people once in the same school"), tóngbāntóngxué [same-class-same-study] ("classmates of same department and year"), tóngháng [same-trade] ("person of same profession"), tóngshì [same-matter] ("colleague", i.e. "people who do the same thing"), and tōngbāo [same-afterbirth/sibling] ("offspring of same parents/compatriot").

When a Chinese finds out that another person is tóngxing ("of the same surname"), they will immediately say Wömen wúbăiniánqián shì yijiā ("We are of the same family five hundred years ago"), which is a formulaic expression in situations like this. It is also very common to hear people refer to each other as being tóngnián, tóngsui ("of the same year") or tóngling ("of the same age"). ${ }^{10}$ Fellow in English is probably a near equivalent of tóng. But English speakers do not commonly refer to each other as "fellow X", where X can be place, age, or activity (so that similar experience is implied). A script for the use of tóng $X$ is as follows: 
[H] Cultural script for tóng $X$ ("fellow X")

[people think like this:]

when I say something about another person to someone

it is good if I can say something like this about this person:

I think about this person like this:

I know something about this person

this person can know the same thing about me

when I think about this person like this

I feel something good towards this person because of this

this person can think about me in the same way

when this person thinks about me like this, this person can feel something good towards me because of this

Some of the above-mentioned tóng $X$ expressions can be modified by lăo ("old") to make the relationship between the speaker and the referent sound even closer. This brings our discussion to the use of lăo $X$ ("old $\mathrm{X}$ ") in the next section.

\section{3. lăo $X$ 老 $X$ (“old $X$ ”)}

In a highly interesting and revealing book on Chinese (political) negotiation entitled Chinese Negotiating Behavior: Pursuing Interests Through "Old Friends", the author, a former American ambassador to China, writes that "within that relatively brief period, Kissinger found himself characterized as an 'old friend' by his new Chinese counterparts" (Solomon 1999: x). Calling a foreigner "an old friend of China" during initial encounters can be baffling and striking for cultural outsiders. But it is such an established conventional practice that no book on Chinese negotiation styles fails to mention it. The intended message is clear from the Chinese side: we regard you as someone who has a close relationship with China-us; you are like one of us (thus all the culturally-loaded obligations expected of zijurén, \$2.2). This is because once the relationship between the two sides reaches this "threshold" of being "old", they are like zijurién. In the Chinese language, the expression of lăo $X$ stands almost side-by-side with zijurién. For example, one would often hear people saying "wŏmen shi lăotóngshì le, zìjirén" ("We are fellow colleagues since a long time ago, we're insiders [thus we do not have to be polite to each other]").

It is clear that calling Kissinger an "old friend" (when he obviously was not) is a strategic move employed by his Chinese counterpart to "draw the foreign negotiator into a personal relationship, establish ties of friendship" (Solomon 1999: 21), which, as the author puts it, is "a clear projection of Chinese social practices' (p. 25). 
It is important to note that péngyou , which is often translated as friend in English, does not mean the same as friend (see Wierzbicka 1997 for the meaning of English friend). It is a vague category which says little about the nature of the relationship, since there are so many specific categories referring to human relationships in Chinese culture that are formed on the basis of their shared "sameness" (\$4.2). (Little wonder that kids are addressed and referred to by adults as xiăopéngyŏu ("little friend")). Foreigners are referred to as péngyŏ u previously because of the little shared common ground that they have with the Chinese people. The most important message conveyed by the term péngyou is rather that it is the opposite of enemy.

Clearly, the time factor is at work in the use of "old" (\$2.2). Becoming shú ("cooked/familiar") or shúrén ("acquaintance") is an important step towards being seen as "one of us". When interactants have little in common, time becomes the only thing that can be appealed to in the effort to forge a closer relationship. The script for the use of lăo $X$ is proposed as follows:

[I] Cultural script for use of lăo $X$ (“old X”)

[people think like this:]

when I say something about another person to someone

it is good if I can say something like this:

I think about this person like this:

I have known for a long time who this person is

I have often said things to this person when I saw this person when I think about this person like this

I feel something good towards this person because of this

I can think about this person like I think about a zijurén

\subsection{To be or not to be “polite” “客气” 还是 “别客气”?}

The distinction between zijurrén ("insider") and wàirén ("outsider") is so deep-rooted that it is ubiquitous in Chinese social exchanges and closely tied up with the Chinese notion of "politeness". For example, zijurién biékèqi ("We are insiders, do not be polite") or zijurién bié jiànwài ("We are insiders, do not see outside") are among the most frequently used formulaic expressions, or what Kecskes (2003) calls "situation-bound utterances", exchanged in (informal) social settings. They roughly mean something like this: "Do not stand on ceremony. Forget about the formality. Insiders don't need that". This is because Chinese family members do not usually observe kètào ("polite formula, civilities", DeFrancis 1997: 339), don't say kètàohuà [kètào words] ("polite formula", p. 340) 
or kèqihuà ("polite words/utterance"), such as "thank you", or "please", and don't pay compliments to each other, or ask each other's permission to do something (cf. Ye 2004a). Thus a request such as "Would you please take the camera to the garden, it is photo time, thank you" from a husband to his wife would be unthinkable from a Chinese point of view.

To be kèqi is to observe courtesy and to fulfil the requirements of decorum in social encounters. It is a good thing to be kèqi. However, the catch is that being kèqi inevitably implies a non-zijürén, "far" relationship. It goes against the "from far to close" principle as described in master script [F] (see §2.2). Thus to say words to the effect that "we are insiders, kèqi should be spared" is a pragmatic act intended to shorten the social distance between the interactants. The following script describes this general rule of saying "don't be polite" as a "polite" rule in Chinese social encounters:

\section{[J] Cultural script}

[people think like this:]

people have to do/say some things in some ways when they are with other people if these other people are not zijurén

people don't have to do/say these things in these ways when they are with zijurrén

when a person is with someone else

if this other person is not a zijürén,

it can be good if this person says something like this to this other person:

"when you are with me, I want you to do/say things like you do when you are with zijirrén"

Being kèqi 客气 ("polite") is a notion that is situated and applied in the wider interactional realm of "outsiders". This is hinted in the meaning of kè ("guest/stranger/alien"). So far, kèqì, this important value in Chinese informal social encounters, has not been discussed in the literature on Chinese "politeness". Instead, limào has been treated as the Chinese first-order politeness (i.e. politeness1, after Watts et al. 1992), which was first proposed by Gu (1990; see also Mao 1994, Lee-Wong 2000). However, $\mathrm{Gu}$ (1990: 239) rightly pointed out the moral dimension that characterizes limào, reflected in the very word lǐ-"referring to social hierarchy and order". But, Gu fails to point out that limào is used prototypically to describe children's behavior towards adults (thus, respectful behavior towards senior members of the society). Limmào is essentially located in the moral world, where hierarchical, asymmetrical relationships are pre-established and fixed; whereas kèqi is applied in the adult, informal social world between shúrén. It is more of an attitude than social conduct, built into routine conversations and formulaic talks between people, 
whose relationships are negotiable. This is supported by the informants' observation in Pye's (1982) study that the hierarchical relationship within a Chinese negotiation team seems to succumb to an insider relationship. It seems that for the notion of Chinese "politeness" to be at least plausible, the salient folk notion of kèqi has to be included.

\section{Theoretical and practical implications}

An ethnopragmatic perspective afforded by linguistic evidence and examples from real-life intercultural encounters, and a culture-independent semantic theory NSM, has allowed this study to reveal the cultural logic inherent in Chinese social interaction, which moulds Chinese cultural patterns and social practice. It has yielded fruitful results on two fronts. On the theoretical side, it has shown that knowledge of the fundamental categories of Chinese interpersonal relationships is crucial for a full grasp of the cultural mechanisms that govern Chinese ways of speaking. Thus, this study has fulfilled its initial goal of making a strong case for treating interpersonal relationships as a theoretical variable in studies of pragmatics and human interaction. The conceptual foundation of Chinese social interaction is fundamentally different from the one upon which Brown and Levinson's (1987, hereafter B \& L) model of social interaction is built, in that the key force in Chinese social interaction is along the "outsiderinsider" continuum, pulling the relationship between interactants towards the central figure. This explains the confusion and inconsistency that surrounds the characteristics of Chinese communicative styles as described in the existing literature, which some studies describe as oriented towards "negative politeness", and others describe as oriented towards "positive politeness". This study dispels such confusion. A corollary of uncovering the cultural logic of Chinese social interaction is that "face", the pillar concept in B \& L's theory of politeness, and the focus of most, if not all, Chinese studies on pragmatics, does not play such an important role as is often assumed ("face" is an important concept in Chinese culture, but not the key intersection of the general design of Chinese social pattern). Thus, Lim's (1994) attempt to use the variable of face to explain interpersonal relationships is like "putting the cart before the horse". Pan (2000: 6) describes how over-emphasis on the concept of face spells disaster for students in social encounters in China. Pan's concern is shared by many language teachers. It is obvious from this study that Chinese people do not have the need to attend to another's face wants or needs if this person is seen as an "outsider". This speaks volumes of the importance of dis- 
covering what is basic, important and fundamental to the actors in their social reality, not only in theory-making but also in practice.

On the practical side, this paper has shown that theoretical discussion and empirical study can feed each other. Discussion throughout the paper has drawn observations and insights from studies of Chinese interactional style and social behavior driven by the practical needs of trying to understand and make sense of Chinese interactional behavior in political and business negotiations. These studies offer hands-on advice and manual-like instruction that people in real life can apply immediately. Most interestingly, they unanimously point out that failure to understand the meaning of Chinese "friendship" and the role that relationships play in Chinese social organization lies at the heart of miscommunication and unsuccessful negotiation outcomes. This study has shown how conceptual analysis can provide an explanation for common social practices.

It can be expected that cultures differ in the emphasis they place on certain demarcations of interpersonal relationships, which are psychologically important to its people, and which highlight fundamental differences in the norms of social behavior. This paper hopes to generate further interest in systematic, cross-cultural, investigation of the ways in which human relationships are conceptualized and of their role in social interaction. Research in this direction will shed light on both the commonality and the differences in ways of human interaction.

\section{Appendix: Explication of shúrén using Chinese semantic primes}

熟人

(a) 有些人, 人们能这样看待他们:

(b) 我已经知道这个人是谁有一段时间了

(c) 这个人知道我是谁有一段时间了

(d) 一段时间前, 我不能这样想

(e) 后来, 我看到这个人的时候, 跟这个人说了话

(f) 同时, 这个人跟我说了话

（g）像这样子有了一段时间

(h) 因此现在我能像人们知道对方是谁那样来跟这个人说话

(i) 人们不能这样看待所有的人

(j) 人们不得不以另一种方式看待另一些人。

\section{Notes}

1. An earlier version of the paper was presented at the Second Symposium on Intercultural, Cognitive and Social Pragmatics (EPICS II), held in the University of Sevilla, 
Spain, May 26-28, 2004. I wish to thank Prof. Istvan Kecskes for his encouragement and valuable suggestions. I am indebted to Prof. Anna Wierzbicka for her valuable comments, suggestions, and support over the year.

2. English glosses for specific Chinese expressions throughout the paper are drawn from the following three dictionaries: Liang (1973), DeFrancis (1997), and JYHC (2000), the most popular bilingual dictionary for Chinese language learners around the world.

3. Due to space limitations, only the English translations of the original Chinese examples can be provided.

4. Xuèyuán ('blood affinity') and dìuán ('place affinity') are two of the most important cultural "complexes" that grow out of the traditional agrarian Chinese society. They deserve a separate, detailed study.

5. Scholars and commentators on Chinese culture have often pointed out the indifference of the Chinese people towards strangers and lamented their lack of public spirit. This often leads them to depict Chinese people as individualistic or "egocentric".

6. Studies of Chinese social interaction from various fields, such as sociology, anthropology, social psychology and business communication, have all paid close attention to the concept of guānxi ("interpersonal relationship/connections"). Although it is impossible to devote space to discussing this keyword here, this study will contribute to the understanding of the operational mechanism of guänxi.

7. Questions in "greetings" are formed by rising tone or by adding those sentence-final particles that function like tag-questions.

8. Dă zhāohu is polysemous. Shen (1998: 70) explains the other sense as "to notify those concerned before or after some work or problem to be dealt with". The two senses are related to what interactants say.

9. Instead, wènhò can be used, which is more like the "greeting" in the sense of "New Year Greetings". Wènhòu is mostly concerned with health.

10. The only exception is tóngzhì [same-purpose/aspiration] ("comrade"). It can only be used as a form of address.

\section{References}

Blackman, Carolyn. 1997. Negotiating China: Case Studies and Strategies. St. Leonards, NSW: Allen \& Unwin.

Brown, Penelope, and Stephen C. Levinson. 1987. Politeness: Some Universals in Language Usage. Cambridge: Cambridge University Press.

Chen, Yingfang (ed.). 2003. Yimín Shànghăii: 52 Rén Kŏushù Shílù [Migrating to Shanghai: A Faithful Oral Recording of 52 Migrants]. Shanghai: Shanghai Xuélín Chūbănshè.

DeFrancis, John (ed.) 1997. Alphabetically Based Computerized Chinese-English Dictionary. St. Leonards, NSW: Allen \& Unwin.

Duranti, Alessandro. 1997. Universal and culture-specific properties of greetings. Journal of Linguistic Anthropology 7(1):63-97.

Fei, Xiaotong. 1937. Xiāngtŭ Zhōngguó [Earthbound China]. Beijing: Shāngwù.

Firth, Raymond. 1972. Verbal and bodily rituals of greeting and parting. In J. S. La Fontaine (ed.), The Interpretation of Ritual: Essays in Honour of A. I. Richards. London: Tavistock Publications. 1-38.

Gao, Ge, Stella Ting-Toomey, and William Gudykunst. 1996. Chinese communication process. In Michael H. Bond (ed.), Handbook of Chinese Psychology. Hong Kong: Oxford University Press. 290-293. 
Goddard, Cliff and Anna Wierzbicka (eds.). 2002. Meaning and Universal Grammar Theory and Empirical Findings (2 Volumes). Amsterdam: John Benjamins.

$\mathrm{Gu}$, Yueguo. 1990. Politeness phenomena in modern China. Journal of Pragmatics 14(2):237-257.

Hymes, Dell H. 1962. The ethnography of speaking. Reprinted in Joshua Fishman (ed.) 1968. Readings on the Sociology of Language. The Hague: Mouton. 99-138.

JYHC. 2000. Jīngxuăn Yīnghàn Hànyīng Cídiăn [The Concise English-Chinese ChineseEnglish Dictionary]. (2nd edn.). Hong Kong: Oxford University Press.

Kecskes, Istvan. 2003. Situation-Bound Utterances in L1 and L2. Berlin/New York: Mouton de Gruyter.

Lee-Wong, Song Mei. 2000. Politeness and Face in Chinese Culture. Frankfurt am Main: Peter Lang.

Lim, Tae-Seop. 1994. Facework and interpersonal relationships. In Stella Ting-Toomey (ed.). The Challenge of Facework: Cross-Cultural and Interpersonal Issues. Albany: State University New York. 209-230.

Mao, Luming Robert. 1994. Beyond politeness theory: 'face' revisited and reviewed. Journal of Pragmatics 21(5):451-486.

Markus, Hazel Rose and Shinobu Kitayama. 1991. Culture and the self: implications for cognition, emotion and motivation. Psychological Review 98: 224-253.

Mey, Jacob. 2001. Pragmatics. London: Blackwell.

Pan, Yuling. 2000. Politeness in Chinese Face-to-Face Interaction. Stamford: Ablex.

Pye, Lucian. 1982. Chinese Commercial Negotiating Style. Cambridge, Mass: Oelgeschlager, Gunn \& Hain.

Shen, Shanhong. 1998. Zhāngguó Yüyán Wénhuà Bèijĭng Shuāngjiě Cídiăn [A ChineseEnglish Dictionary with Cultural Background Information]. Beijing: The Commercial Press.

Soloman, Richard H. 1999. Chinese Negotiating Behavior: Pursuing Interests Through "Old Friends" (with a new essay Chas W. Freeman, Jr.). Washington: United States Institute of Peace.

SQ. 1993. Qiüjú Dăguānsi [The Story of Qiuju] (Directed by Zhang Yimou). CA: Columbia Tristar Home Video.

Watts, Richard, Sachiko Ide, and Konrad Ehlich. 1992. Introduction. In Richard Watts, Sachiko Ide, Konrad Ehlich (eds.), Politeness in Language: Studies in its History, Theory and Practice. Berlin: Mouton de Gruyter. 1-17.

Wierzbicka, Anna. 1997. Understanding Cultures through their Key Words: English, Russian, Polish, German, Japanese. New York: Oxford University Press.

- 2002. Semantic primes and universal grammar in Polish. In C. Goddard, A. Wierzbicka (eds.), Meaning and Universal Grammar - Theory and Empirical Findings (vol. 2). Amsterdam: John Benjamins. 65-144.

- 2003a. Introduction. In Cross-Cultural Pragmatics: The Semantics of Human Interaction. (2nd edn.). Berlin: Mouton de Gruyter. v-xxvii.

- 2003b. Russian cultural scripts: The theory of cultural scripts and its applications. Ethos 30(4):401-432.

Ye, Veronica Zhengdao. 2004a. 'La Double Vie de Veronica': Reflections on my life as a Chinese migrant in Australia. Life Writing 1(1):133-146.

Ye, Zhengdao. 2004b. The folk model of Chinese facial expressions: a linguistic perspective. Culture and Psychology 10(2):195-222.

- In press. Why the inscrutable Chinese face? In Cliff Goddard (ed.), Ethnopragmatics. New York/Berlin: Mouton de Gruyter. 